\title{
KEEFEKTIFAN PENGGUNAAN GOOGLE CLASS ROOM DAN ZOOM SELAMA PANDEMI COVID 19 PADA PEMBELAJARAN MATEMATIKA
}

\author{
Marlinda Indah Eka Budiarti ${ }^{1}$; Tri F.R . Titing ${ }^{2}$; \\ Kusuma Dhipanusa $^{3}$; Muji Setiyono ${ }^{4}$; Carles Y.A Nalle ${ }^{5}$
}

${ }^{1}$ Politeknik Pelayaran Sorong

\begin{abstract}
Abstrak
Penelitian ini bertujuan untuk mengetahui keefektifan penggunaan google class room dan zoom selama pandemi covid 19 pada pembelajaran matematika. Metode penelitian yang akan digunakan adalah kuantitatif dekskritif. Subjek penelitian diperoleh dari peserta didik di poltek pelayaran yang diberikan kuesioner yang berisi jenis pertanyaan tertutup, semi tertutup, dan terbuka yang dibagikan menggunakan google form. Target capaian penelitian ini melihat dan memberikan solusi dari hasil penelitian efektivitas penggunaan google class room dan zoom selama pandemi covid 19 pada pembelajaran matematika.
\end{abstract}

\section{Kata Kunci: Efektivitas, Google Class room, Zoom, Matematika}

\section{PENDAHULUAN}

Pada saat pandemi covid ini sangat sulit melakukan pembelajaran melalui tatap muka. Banyak sekolah beralih keberbagai pembelajaran e-learning. Salah satu pembelajaran e-learning ialah aplikasi google class room dan zoom.E-learning adalah teknologi informasi dan komunikasi untuk mengaktifkan mahasiswa untuk belajar kapanpun dan dimanapun (Dahiya,2012).

Ada tiga hal penting sebagai persyaratan kegiatan belajar elektronik (elearning), yaitu: (a) kegiatan pembelajaran dilakukan melalui pemanfaatan jaringan, dalam hal ini dibatasi pada penggunaan internet, (b) tersedianya dukungan layanan belajar yang dapat dimanfaatkan oleh 1|Jurnal Patria Bahari peserta belajar, misalnya External Harddisk, Flaskdisk, CD-ROM, atau bahan cetak, dan (c) tersedianya dukungan layanan tutor yang dapat membantu peserta belajar apabila mengalami kesulitan (Hartanto,2016).

Di samping ketiga persyaratan tersebut di atas masih dapat ditambahkan persyaratan lainnya, seperti adanya: (a)lembaga yang menyelenggarakan dan mengelola kegiatan e-learning, (b) sikap positif dari peserta didik dan tenaga kependidikan terhadap teknologi komputer dan internet, (c) rancangan sistem pembelajaran yang dapat dipelajari dan diketahui oleh setiap peserta belajar, (d) sistem evaluasi terhadap kemajuan atau perkembanganbelajar peserta belajar, dan (e) mekanisme umpan balik yang dikembangkan oleh lembaga 
penyelenggara (Hartanto,2016).

Akan tetapi kenyataan dilapangan pada saat mahasiswa dipulangkan pada saat pandemi, banyak yang berdomisili dipulau kecil yang mana di daerah tersebut susah adanya signal, yang mana pastinya menganggu pembelajaran e-learning. Penggunaan elearning yang dimaksud pada penelitian ini ialah zoom dan google class room.

Adapun bebrapa penelitian terkait google class room sebagai berikut: 1) menurut (Utami, R: 2019) menunjukkan bahwa Respon yang baik ditunjukan oleh mahamahasiswa dalam penggunaan Google Classroom sehingga Google Classroom dapat digunakan untuk memperlancar proses pembelajaran; 2) menurut Gunawan (2018) menunjukkan Hasil dari penelitian menunjukkan bahwa keterlaksanaan sebesar $88 \%$ dari rencana awal. Penggunaan Google Classroom berjalan secara optimal. Hal tersebut dapat terlihat dari hasil pekerjaan yang diperoleh dari mahasiswa serta dari hasil yang dikemukakan oleh mahasiswa melalui kuesioner terbuka. Selain itu, pembelajaran dengan Google Classroom memiliki efektivitas untuk menunjang keterampilan pemecahan masalah dari mahasiswa tersebut, di mana dapat dilihat dari hasil yang dikemukakan oleh mahasiswa; dan 3) menurut Nuraini ( 2020) menunjukkan Hasil penelitian $2 \mid J u r n a l$ Patria Bahari menunjukkan bahwa aplikasi google classroom dapat membantu serta memudahkan guru dan mahasiswa dalam melaksanakan proses pembelajaran jarak jauh. Berdasarkan hasil penelitian maka dapat disimpulkan bahwa pembelajaran daring menggunakan aplikasi google classroom terbukti efektif dilaksanakan pada masa WFH akibat pandemi covid-19. Pemanfaatan google classroom dapat di terima dan dikembangkan lebih lanjut meskipun masih membutuhkan pembenahan dari sisi ketersediaan sumber daya pendukung.

Adapun beberapa penelitian tentang penggunaan aplikasi zoom sebagai berikut: 1) menurut Kusuma (2020) menunjukkan bahwa Hasil penelitian menunjukan bahwa hasil belajar matematika kedua kelas sama sebelum diberi perlakuan dan hasil belajar matematika kedua kelas berbeda setelah diberi perlakuan atau dengan kata lain kelas yang diberikan Perlakuan Webinar Zoom lebih baik dari pada kelas yang diberikan Perlakuan WA Group dan 2) menurut Rohiman (2019) menunjukkan Hasil utama penelitian ini adalah media pembelajaran matematika menggunakan software Prezi. Kualitas media pembelajaran matematika menggunakan software Prezi adalah sangat baik berdasarkan hasil validasi ahli media 
dengan skor $93 \%$ dan berdasarkan ahli materi adalah baik dengan skor 77,5\%, dan respon peserta didik terhadap media pembelajaran adalah sangat baik dengan skor $83,9 \%$ dengan menggunakan skala Liker.

Maka dari itu peneliti ingin melihat gambaran dari penggunaan e-learning pada saat pandemi covid pada pembelajaran matematika.adapun perbedaan penelitian dengan penelitian terdahulu adalah, penggunaan google class room dan aplikasi zoom. Serta perbedaan kondisii daerah yang ada di pulau papua.

\section{Tujuan Penelitian}

Berdasarkan rumusan masalah diatas, maka tujuan yang dicapai dalam penelitian ini adalah, sebagai berikut:

1. Untuk mengetahui seberapa besar kepuasan yang diperoleh mahasiswa setelah menggunakan aplikasi zoom dalam pandemi covid 19 pada pembelajaran matematika?

2. Untuk mengetahui seberapa besar kepuasan yang diperoleh (Gratifications Obtained) Mahasiswa setelah menggunakan aplikasi Google Class room dalam pandemi covid pada pembelajaran matematika?

\section{Manfaat Penelitian}

Adapun manfaat dalam penelitian ini, adalah:
1. Dapat mengetahui seberapa besar kepuasan yang diperoleh mahasiswa setelah menggunakan aplikasi zoom dalam pandemi covid 19 pada pembelajaran matematika?

2. Dapat mengetahui seberapa besar kepuasan yang diperoleh (Gratifications Obtained) Mahasiswa setelah menggunakan aplikasi Google Class room dalam pandemi covid pada pembelajaran matematika?

\section{TINJAUAN}

\section{PUSTAKA}

\section{Aplikasi Google Class room}

Google classroom adalah aplikasi yang dibuat oleh google yang bertujuan untuk membantu dosen dan mahapeserta didik apabila kedua hal tersebut berhalangan, mengorganisasi kelas serta berkomunikasi dengan peserta didik tanpa harus terikat dengan jadwal kuliah di kelas. Disamping itu dosen dapat memberikan tugas dan langsung memberikan nilai kepada mahamahasiswa. Penyampaian pembelajaran dengan e-learning merupakan pembelajaran dengan memanfaatkan teknologi internet untuk meningkatkan lingkungan belajar dengan konten yang kaya dengan cakupan yang luas. E-learning merupakan pemanfaatan media pembelajaran menggunakan internet, 
untuk mengirimkan serangkaian solusi yang dapat meningkatkan pengetahuan dan keterampilan. Setiap metode pembelajaran harus mengandung rumusan pengorganisasian bahan pelajaran, strategi penyampaian, dan pengelolaan kegiatan dengan memperhatikan faktor tujuan belajar, hambatan belajar, karakteristik peserta didik, agar dapat diperoleh efektivitas, efisiensi, dan daya tarik pembelajaran (Sabran, 2019).

\section{Aplikasi Zoom}

Zoom meet merupakan Platform Tatap muka yang bersifat Conference dimana Pendidik dan peserta didik bisa langsung berinteraksi selayaknya bertemu langsung. Dalam Aplikasi ini terdapat banyak fitur mulai dari File sharing dalam format PDF bisa dilakukan dengan mudah, Zoom menawarkan fasilitas yang paling mudah untuk individu mau bergabung dengan conference/meeting hanya dengan tautan atau nomor kamar, Zoom synchronous online formats juga meliputi two-way live broadcast lectures, Zoom menjadikan kursus online menjadi sangat populer karena menghemat biaya waktu perjalanan, biaya bahan bakar, dan dampaknya terhadap lingkungan. Zoom memiliki biaya finansial yang rendah dan menawarkan pengalaman webinar yang bagus Menggunakan Zoom memungkinkan untuk menulis dan berbicara bersama melalui proses. Zoom dapat digunakan dalam Opsi Pendidikan Jarak Program Pekerjaan Sosial Discussions were two-way audiovisual, Zoom digunakan untuk telemedicine kesehatan dalam menanggapi pandemi COVID-19 2020, Zoom untuk diskusi berbasis komunitas, dll.(Abdillah \& Darma, 2020)

\section{KerangkaPemikiran}

Pada era pandemi covid 19 sangat sulit melakukan pembelajaran dikelas seperti biasa, makadari itu dengan memanfaatkan teknologi

dilakukanlah pembelajaran dengan metode e- learning yang mana salah satunya ialah penggunaan metode pmenggunakan aplikasi Google Class Room dan aplikasi zoom. Penggunaan aplikasi ini dalam pembelajaran, diharapkan adanya feedback yang mana peneliti ingin mengetahui efektivitas pembelajaran dari aplikasi ini yang mana diharapkan adanya evaluasi dalam pembelajaran selanjutnya.

\section{METODE PENELITIAN}

Tempat dan WaktuPenelitian

Penelitian akan dilaksanakan di Politeknik Pelayaran Sorong dan poltek 
saint paul pada bulan agustus sampai september 2020.

\section{Metode dan Jenis Penelitian}

Metode penelitian yang dipakai dalam penelitian ini adalah metode peneltian survai (Kriyantono, 2006). SedangkanJenis penelitian ini adalah penelitian deskriptif, yang ditujukan untuk menggambarkan fenomena-fenomena apa adanya. Penelitian deskriptif tidak memberikan perlakuan, manipulasi, tetapi menggambarkan suatu kondisi apa adanya. Dalam penelitian ini deskriptif yang dimaksud adalah deskriptif kuantitatif karena gambarannya menggunakan ukuran, jumlah, atau frekuensi (Syaodih, 2006 ).

\section{Desain Penelitian}

Desain yang digunakan dalam penelitian ini adalah Survei Descriptive Design. Adapun langkah-langkah yang dilaksanakan dalam penelitian ini, antara lain: a) Memilih dan merumuskan masalah. Masalah yang akan diteliti yaitu bagaimana mengetahui kepuasan mahasiswa terhadap guru mata pelajaran matematika dari aspek pengunaan google class room dan zoom. b) Menentukan tujuan dari penelitian yang akan menjawab rumusan masalah. c) Memberikan batasan-batasan peneltian dan menentukan sampel. d) Menyusun tinjauan pustaka yang kuat. e) Menyusun instrument pengumpulan data. f) Melakukan pengumpulan data, teknik pengumpulan data yang digunakan adalah lembar observasi kepuasan mahasiswa terhadap guru matematika dan kuesioner yang telah $5 \mid J u r n a l$ Patria Bahari diujicobakan terlebih dahulu,. Lembar observasi kepuasan mahasiswa terhadap gurunya difungsikan untuk mengukur keefektifan penggunaan aplikasi google class room dan aplikasi zoom. Kuesioner digunakan untuk mengukur tingkat kepuasan mahasiswa dari dua aspek, yaitu keefektifitasan penggunaan aplikasi dan evaluasi dari pembelajaran penggunaan aplikasi.Selain kuesioner, dilakukan juga tes wawancara agar dapat diketahui letak kurang maksimalnya penggunaan aplikasi g) melakukan analisis data yang akan dibahas pada teknik analisis data. h) Mengintepretasikan hasil dan menarik kesimpulan.

\section{Populasi dan Sampel}

Populasi dalam penelitian ini ialah semua mahasiswa Poltek Pelayaran Sorong dan poltek saint paul. Sedangkan sampel dari penelitian ini adalah mahasiswa poltek pelayaran sorong dan poltek saint paul yang mempelajari matematika. pengambilan sampel dilakukan dengan tekhnik Simple Random Sampling, yaitu diambil secara acak tanpa mempertimbangkan kelas yang dominan atau tidak.

\section{Variabel Penelitian}

Variabel Penelitian Menurut Sugiyono (2012: 60) variabel penelitian pada dasarnya 
adalah segala sesuatu yang berbentuk apa saja yang ditetapkan oleh peneliti untuk dipelajari sehingga diperoleh informasi tentang hal tersebut, kemudian ditarik kesimpulannya. Variabel penelitian merupakan sesuatu yang akan diteliti dan dipelajari oleh peneliti, kemudian peneliti akan membuat kesimpulan dari data informasi yang telah diperoleh. Agar tidak terjadi kesalahan dalam menafsirkan konsep variabel yang diteliti, maka variabel tersebut perlu diidentifikasi dan didefinisikan secara operasional.Variabel Bebas (Variabel Independen) adalah variabel yang perubahannya atau timbulnya variable terikat atau independen Sugiyono (2012: 39)

Teknik dan Instrumen Pengumpulan Data

Data yang diperoleh dalam penelitian ini adalah berupa hasil observasi keterlaksanaan pembelajaran, hasil pengisian angket dari dua indikator, dan wawancara secara langsung dari guru mata pelajaran matematika. Data tambahan sebagai bahan pertimbangan yaitu dokumentasi-dokumentasi untuk menggambarkan secara visual proses pembelajaran yang telah dilaksanakan. Dalam pengumpulan data dalam penelitian ini, teknik yang digunakan adalah sebagai berikut:

a) Penyusunan Instrumen Penelitian

Tahap ini dilakukan sebelum melaksanakan penelitian. Instrumen yang disusun terdiri dari: kisi-kisi lembar observasi keterlaksanaan pembelajaran, mempengaruhi atau yang menjadi sebab

kisi-kisi angket kepuasan mahasiswa terhadap guru mata pelajaran matematika, kisi-kisi angket kepuasan mahasiswa terhadap guru mata pelajaran matematika dari aspek keefektifan penggunaan aplikasi, kisi-kisi wawancara, lembar observasi keterlaksanaan pembelajaran, dan lembar pedoman wawancara.

1. Validasi instrumen penelitian. Dalam kegiatan ini dilakukan 2 (dua) tahap validasi, yaitu validasi isi dengan penilaian dilaksanakan oleh dosen ahli, dan validasi konstruk yaitu dengan mengujicobakan instrumen kepada responden yang memiliki karakteristik sama.

2. Pengumpulan Data

Pada tahap ini dilakukan survei kepuasan mahasiswa dan pembelajaran dilaksanakan sebanyak 2 (dua) pertemuan.

3. Analisis Data Analisis data dilakukan setelah semua data yang dibutuhkan telah terkumpul. Data dibuat dalam bentuk tabel sehingga mudah dibaca dan dipahami secara keseluruhan. Selain menggunakan rumus-rumus yang telah ditentukan, analisis data juga menggunakan software SPSS 20 agar data yang diperoleh semakin akurat.

4. Kesimpulan Setelah data dianalisis, hasil yang diperoleh diambil kesimpulannya dengan melihat apakah tujuan dari penelitian sudah 
tercapai apa belum. Apabila tujuan penelitian belum tercapai maka penelitian dilanjutkan, akan tetapi bila tujuan penelitian telah tercapai maka penelitian dapat dihentikan.

\section{Instrumen Pengumpulan Data}

Instrumen yang digunakan adalah lembar observasi, kuesioner,dan wawncara. Kuesioner digunakan untuk mengukur tingkat kepuasan mahasiswa terhadap guru mata pelajaran matematika, dari aspek penggunaan aplikasi. adapun penjelasan dari instrumen-instrumen yang digunakan yaitu:

\section{Lembar Observasi Keterlaksanaan}

Pembelajaran

Lembar observasi pembelajaran digunakan sebagai pengamat jalannya proses pembelajaran, terutama survei kepuasan mahasiswa terhadap guru mata pelajaran matematika dengan langkahlangkah secara teori. Pengamatan dilakukan oleh observer dengan memberikan tanda centang pada skor dengan ketentuan 1 = tidak baik, $2=$ kurang baik, $3=$ baik, dan $4=$ sangat baik. Untuk lebih jelasnya dapat dilihat dilampiran Kisi-kisi Lembar Observasi Survei Kepuasan Mahasiswa terhadap Guru Mata Pelajaran Matematika.

2. Angket Survei Kepuasan Mahasiswa Terhadap Guru Mata Pelajaran Matematika Pengumpulan data survei kepuasan mahasiswa terhadap guru mata pelajaran matematika. Kemudisn mengisi angket (kuesioner) tertutup dengan skala Likert sehingga responden hanya akan memberika jawaban yang diperlukan untuk kepentingan penelitian. Peneliti memilih menggunakan kuesioner karena teknik pengumpulan data lebih efisien,praktis dan sangat memungkinkan jika digunakan untuk responden yang cukup besar. Responden akan memilih satu jawaban terhadap pertanyaan/ pernyataan dengan cara memberi cheek list $(\sqrt{ })$ pada nomor jawaban yang tersedia. Pemberian skor pada setiap item disesuaikan dengan pertanyaan/pernyataan. Sedangkan alternatif jawaban yang diberikan pada indikator yaitu 1 = tidak baik, 2 = kurang baik, $3=$ baik, dan $4=$ sangat baik .

Pemberian skor pada setiap item pertanyaan disajikan pada tabel berikut ini:

Tabel 1. Pemberian Skor pada Tiap Item Pertanyaan pada angket Aspek Kepuasan Mahasiswa Terhadap Guru Mata Pelajaran Matematika

\begin{tabular}{|c|c|c|}
\hline \multirow[b]{2}{*}{$\begin{array}{l}\text { Jawaban } \\
\text { Alternatif }\end{array}$} & \multicolumn{2}{|c|}{ Skor } \\
\hline & $\begin{array}{c}\text { Pernyataan } \\
\text { positif }\end{array}$ & $\begin{array}{c}\text { Pernyataan } \\
\text { negarif }\end{array}$ \\
\hline Sangat Baik & 4 & 1 \\
\hline Baik & 3 & 2 \\
\hline Kurang Baik & 2 & 3 \\
\hline Tidak Baik & 1 & 4 \\
\hline
\end{tabular}

\section{Angket Survei Kepuasan mahasiswa terhadap Guru Mata Pelajaran} Matematika Dari Aspek pengguanaan aplikasi zoom dan google class room

Pengumpulan data survei kepuasaan mahasiswa terhadap guru mata pelajaran matematika dari Aspek pengguanaan aplikasi zoom dan google class roomjuga menggunakan angket/ kuesioner tertutup dengan skala Likert. Sedangkan alternatif jawaban yang diberikan pada indikator $1=$ 
tidak baik, 2 = kurang baik, 3 = baik, dan 4 = sangat baik. Pada instrumen angket aspek Kreativitas belajar mahasiswa yang berisi 42 butir pertanyaan/pernyataan. Berikut adalah tabel penilaian skor pada tiap item jawaban:

\section{Tabel 2. Pemberian Skor Pada tiap item pertanyaan/pernyataan pada angket aspek pengguanaan aplikasi}

\begin{tabular}{|c|c|c|}
\hline \multirow{2}{*}{$\begin{array}{l}\text { Jawaban } \\
\text { Alternatif }\end{array}$} & \multicolumn{2}{|c|}{ Skor } \\
\hline & $\begin{array}{c}\text { Pernyataan } \\
\text { positif }\end{array}$ & $\begin{array}{c}\text { Pernyataan } \\
\text { negarif }\end{array}$ \\
\hline $\begin{array}{l}\text { Sangat } \\
\text { Sering }\end{array}$ & 4 & 1 \\
\hline Sering & 3 & 2 \\
\hline jarang & 2 & 3 \\
\hline $\begin{array}{c}\text { Kadang- } \\
\text { kadang }\end{array}$ & 1 & 4 \\
\hline
\end{tabular}

\section{Teknik Wawancara}

Teknik ini dilakukan kepada guru matematika untuk memperoleh data antara lain tentang masalah-masalah dalam pembelajaran yang biasa terjadi di SMP Negeri 2 Nanggulan. Masalah yang dimaksud, seperti peran guru, tugas guru, dan cara menumbuhkan rasa percaya diri pada mahasiswa. Pedoman wawancara dengan guru matematika dapat dilihat dilampiran

\section{Validitas dan Reliabilitas Instrumen}

1. Uji Validitas Instrumen

Menurut Anderson, dkk (Suharsimi Arikunto, 2016: 80) menyebutkan "Sebuah tes dikatakan valid apabila tes tersebut mengukur apa yang hendak diukur". Uji validitas dalam penelitian ini akan dihitung menggunakan SPSS

2. Uji Reliabilitas Instrumen

Anderson, dkk (Arikunto, 2010: 239) menyatakan bahwa persyaratan bagi tes, yaitu validitas dan reliabilitas. Dalam hal ini, validitas lebih penting, dan reliabilitas ini perlu karena menyokong terbentuknya validitas. Sebuah tes mungkin reliabel tetapi tidak valid. Sebaliknya, sebuah tes yang valid biasanya reliabel. Sedangkan kriteria yang digunakan untuk menentukan instrumen berdasarkan pendapat Nunnaly dan Kaplan (Sugiyono, 2013: 198) yaitu apabila koefisien reliabelnya $\geq$ 0,70 maka cukup tinggi untuk suatu peneliatian. Uji reliabilitas dengan SPSS.

\section{Teknik Analisis Data}

Menurut Sugiyono (2012: 207) teknik analisis data dalam penelitian deskriptif merupakan tahapan yang penting. Analisis data pada penelitian ini adalah dengan teknik analisis statistik deskriptif kuantitatif. Metode penelitian ini menggunakan metode kuantitatif karena data penelitian berupa angka-angka angket tertutup dan dianalisis menggunakan statistik. Teknik analisis data statistik deskriptif adalah statistik ysng digunakan untuk menganalisis data dengan cara mendeskripsikan atau menggambarkan data yang telah terkumpul sebagaimana adanya tanpa bermaksud membuat kesimpulan yang berlaku untuk umum atau generalisasi. Analisis deskriptif bertujuan untuk memberikandeskripsi mengenai subyek penelitian berdasarkan dua variabel yang diperoleh dari kelompok obyek yang diteliti dan tidak dimaksudkan untuk pengujian hipotesis.

\section{HASIL PENELITIAN}


Pada bab ini akan dipaparkan hasil penelitian: a)respon kepuasan yang diperoleh mahasiswa setelah menggunakan aplikasi zoom dalam pandemi covid 19 pada pembelajaran matematika dan b) respon kepuasan yang diperoleh mahasiswa setelah menggunakan aplikasi google classroom dalam pandemi covid19 pada pembelajaran matematika.

Respon Kepuasan yang Diperoleh Mahasiswa Setelah Menggunakan

\section{Aplikasi Zoom dalam Pandemi Covid}

\section{Pada Pembelajaran Matematika}

Berdasarkan hasil tes Realiabilitas angket penggunaan Aplikasi Google Classroom menggunakan SPSS, didapatlah nilai reabilitas sebesar 0,675.

\section{Uji Realibilitas}

Reliability Statistics

\begin{tabular}{|r|r|}
\hline $\begin{array}{c}\text { Cronbach's } \\
\text { Alpha }\end{array}$ & N of Items \\
\hline, 675 & 8 \\
\hline
\end{tabular}

\section{Uji Validasi}

\begin{tabular}{|c|c|c|c|c|}
\hline \multicolumn{5}{|c|}{ Item-Total Statistics } \\
\hline & $\begin{array}{l}\quad \text { Sc } \\
\text { ale Mean } \\
\text { if Item } \\
\text { Deleted }\end{array}$ & $\begin{array}{c}\text { cale } \\
\text { Varianc } \\
\text { e if Item } \\
\text { Deleted }\end{array}$ & $\begin{array}{l}\text { Cor } \\
\text { rected } \\
\text { Item-Total } \\
\text { Correlatio } \\
\mathrm{n}\end{array}$ & $\begin{array}{l}\text { Cro } \\
\text { nbach's } \\
\text { Alpha if } \\
\text { Item } \\
\text { Deleted }\end{array}$ \\
\hline & 29 & 8 & ,61 &, 566 \\
\hline tem1 & , 1299 & ,205 & 6 & \\
\hline & 29 & 1 & - & ,746 \\
\hline tem 2 & ,2468 & 2,462 & 053 & \\
\hline I & & 5 &, 88 & ,427 \\
\hline tem3 & ,4740 & ,284 & 8 & \\
\hline I & 29 & 7 & ,91 & ,456 \\
\hline tem4 & ,9675 & ,077 & 9 & \\
\hline I & 30 & 1 & ,44 & ,634 \\
\hline tem5 & ,2468 & 0,854 & 5 & \\
\hline & 28 & 1 & - & ,708 \\
\hline tem6 &, 7273 & 3,128 &, 125 & \\
\hline I & 28 & 1 &, 00 & ,689 \\
\hline tem7 &, 5584 & 2,928 & 0 & \\
\hline I & 28 & & 00 & ,689 \\
\hline tem8 &, 5584 & 2,928 & 0 & \\
\hline
\end{tabular}

9|Jurnal Patria Bahari
Berdasarkan hasil penyebaran angket yang telah dilakukan pada poltek pelayaran Sorong dan poltek saint paul didapatlah hasil dari 154 responden, sebagai berikut:

Tabel 3. Kepuasan Mahasiswa Menggunakan Aplikasi Zoom dalam Pandemi Covid 19 Pada Pembelajaran Matematika

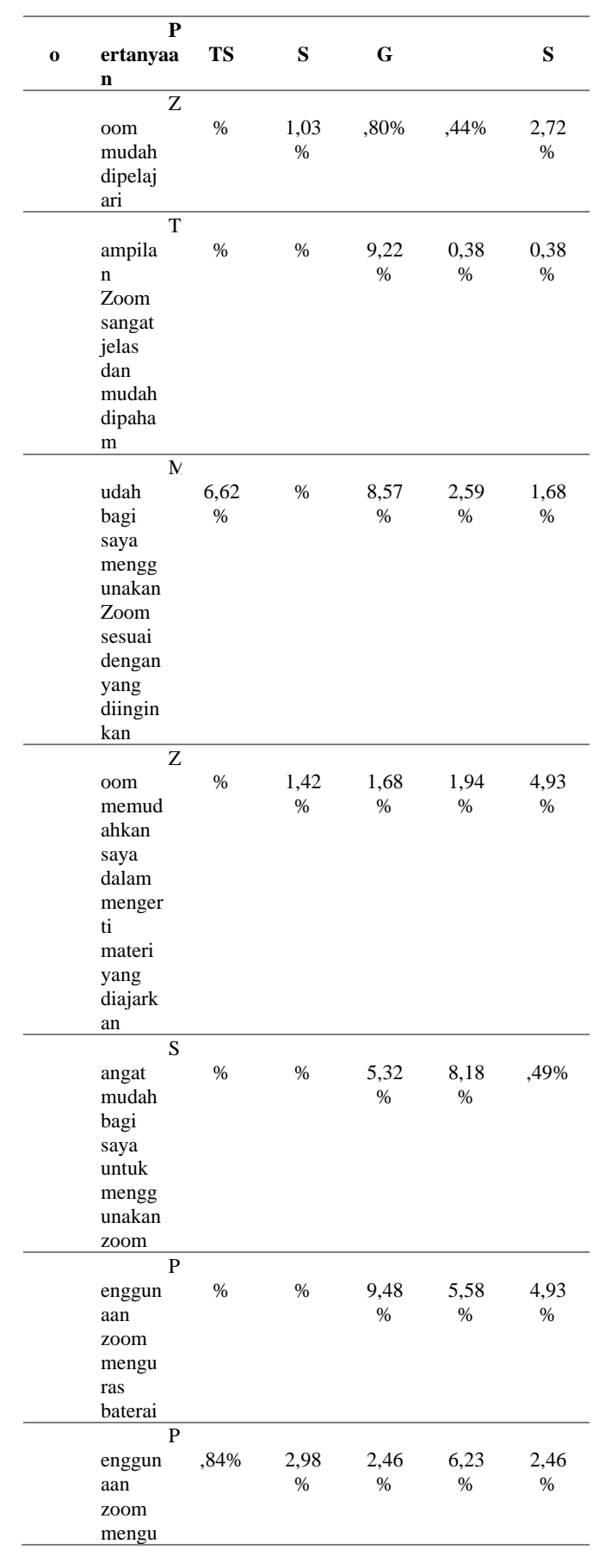






Berdasarkan hasil penyebaran angket didapatlah rata-rata hasil respon mahasiswa dalam penggunaan zoom.

Tabel 4. Rata-Rata Kepuasan Mahasiswa Menggunakan Aplikasi Zoom dalam Pandemi Covid 19 Pada Pembelajaran Matematika

\begin{tabular}{|c|c|c|}
\hline No & Pertanyaan & Rata-Rata \\
\hline 1 & $\begin{array}{l}\text { Zoom mudah } \\
\text { dipelajari }\end{array}$ & 4,42 \\
\hline 2 & $\begin{array}{l}\text { Tampilan } \\
\text { Zoom sangat jelas } \\
\text { dan mudah dipaham }\end{array}$ & 4,31 \\
\hline 3 & $\begin{array}{l}\text { Mudah bagi } \\
\text { saya menggunakan } \\
\text { Zoom sesuai dengan } \\
\text { yang diinginkan }\end{array}$ & 3,08 \\
\hline 4 & $\begin{array}{l}\text { Zoom } \\
\text { memudahkan saya } \\
\text { dalam mengerti } \\
\text { materi yang diajarkan }\end{array}$ & 3,59 \\
\hline 5 & $\begin{array}{l}\text { Sangat mudah } \\
\text { bagi saya untuk } \\
\text { menggunakan zoom }\end{array}$ & 3,31 \\
\hline 6 & $\begin{array}{ll} & \text { Penggunaan } \\
\text { zoom } & \text { menguras } \\
\text { baterai } & \\
\end{array}$ & 4,42 \\
\hline 7 & $\begin{array}{l}\text { Penggunaan } \\
\text { zoom menguras data } \\
\text { paket }\end{array}$ & 3,67 \\
\hline 8 & $\begin{array}{l}\text { Mudah bagi } \\
\text { saya menggunakan } \\
\text { zoom pada saat tidak } \\
\text { stabilnya signal }\end{array}$ & 2,92 \\
\hline
\end{tabular}

Berdasarkan hasil penyebaran angket didapatlah rata-rata setiap itemnya, sebagai berikut:1) item 1 dengan besaran rata-rata 4,$42 ; 2$ ) item 2 dengan besaran rata-rata 4, 31 ;3) item 3 dengan besaran rata-ratanya 3,$08 ; 4)$ item 4 dengan rata-rata sebesar 3,59; $10 \mid$ Jurnal Patria Bahari 5)item 5 dengan rata-rata sebesar 3,31;

6) item 6 dengan rata-rata sebesar 4,42; 7) item 7 dengan rata-rata sebesar 3,67 dan 8) item 8 dengan rata-rata sebesar 2,92. Hal ini menyatakan bahwa pada rata-rata 4,42 Zoom memudahkan responden dalam mengerti materi yang diajarkan, dengan besaran responden 4,42 berarti zoom efektif. Selanjutnya dengan mendapatkan nilai rata-rata sebesar 4,31 dapat dikatakan bahwa responden menilai bahwa tampilan Zoom sangat jelas dan mudah dipaham, sehingga zoom efektif dalam efektif dalam mendisign tampilan. Kemudian pada item 3 dapat dikatan cukup efektif, dengan rata-rata 3,08 yang berarti cukup mudah bagi responden menggunakan Zoom sesuai dengan yang diinginkan. Selanjutnya pada item 4 dapat dikatakan cukup efektif dengan rata-rata 3,59 yang mana berarti Zoom memudahkan bagi responden dalam mengerti materi yang diajarkan. Pada item 5 dapat dikatakan cukup efektif hal ini dapat dilihat dari besaran rata-rata 3,31 yang mana responden menganggap kurang mudah bagi responden untuk menggunakan zoom. Kemudian pada item 6 dapat dikatakan efektif. Hal ini dapat dilihat dari rata-rata sebesar 4,42. Kemudian pada item 7 dapat dikatakan tidak efektif hal ini dapat dilihat dari hasil respon penggunaan zoom menguras data paket. 
Selanjutnya pada item 8 dapat dilihat dari rata-rata 2,92 yaitu berkaitan dengan ketidak mudahan bagi zoom untuk stabil pada saat signal yang buruk.

Berdasarkan hasil angket dapat dilihat mayoritas pada penggunaan Aplikasi Zoom merasakan ketidak puasan. Hal ini dapat dilihat dari presentase dari setiap item perskalanya.yang mana mayoritas memilih ragu-ragu. Hal ini sejalan dengan hasil wawancara bahwa, keseluruhan penggunaan Zoom cukup jelas dan dimengerti. Akan tetapi Aplikasi ini kurang baik karena boros terhadap pemakaian data paket, baterai serta pada daerah papua khususnya kurang baik untuk digunakan yang dikarenakan kurang stabilnya signal. Hal ini sejalan dengan beberapa hasil penelitiannya yang menyatakan bahwa borosnya data paket merupakan poin penting dalamefektifitas pembelajaran menggunakan Zoom( Monica, J., \& Fitriawati, D, 2020; Ismawati, D., \& Prasetyo, I. , 2020)

\section{Respon Kepuasan yang Diperoleh Mahasiswa Setelah Menggunakan Aplikasi Google Classroom dalam Pandemi Covid19 Pada Pembelajaran Matematika}

Berdasarkan hasil tes Realiabilitas angket penggunaan Aplikasi Google
Classroom menggunakan SPSS, didapatlah nilai reabilitas sebesar 0,940.

\section{Uji Reabilitas}

Reliability Statistics

\begin{tabular}{|r|r|}
\hline Cronbach's Alpha & N of Items \\
\hline, 940 & 5 \\
\hline
\end{tabular}

\section{Uji Validitas}

\begin{tabular}{|c|c|c|c|c|}
\hline \multicolumn{5}{|c|}{ Item-Total Statistics } \\
\hline & $\begin{array}{l}\text { Sc } \\
\text { ale Mean } \\
\text { if Item } \\
\text { Deleted }\end{array}$ & $\begin{array}{c}\text { cale }^{\mathrm{S}} \\
\text { Varianc } \\
\text { e if Item } \\
\text { Deleted }\end{array}$ & $\begin{array}{c}\quad \text { Cor } \\
\text { rected } \\
\text { Item-Total } \\
\text { Correlatio } \\
\mathrm{n}\end{array}$ & $\begin{array}{l}\quad \text { Cro } \\
\text { nbach's } \\
\text { Alpha if } \\
\text { Item } \\
\text { Deleted }\end{array}$ \\
\hline $\begin{array}{ll}\text { tem1 } & \text { I } \\
& \text { I } \\
\text { tem2 } & \text { I } \\
\text { tem3 } & \text { I } \\
\text { tem4 } & \text { I } \\
\text { tem5 }\end{array}$ & $\begin{array}{r}14 \\
, 9145 \\
15 \\
, 3618 \\
14 \\
, 7566 \\
14 \\
, 9013 \\
14 \\
, 9605\end{array}$ & $\begin{array}{r}1 \\
6,039 \\
2 \\
0,524 \\
1 \\
8,742 \\
1 \\
8,103 \\
1 \\
9,826\end{array}$ & $\begin{array}{r}, 93 \\
8 \\
, 74 \\
8 \\
, 92 \\
5 \\
, 91 \\
7 \\
, 70 \\
0\end{array}$ & ,911 \\
\hline
\end{tabular}

Berdasarkan hasil penyebaran angket yang telah dilakukan pada poltek pelayaran Sorong dan poltek saint paul didapatlah hasil dari 154 responden, sebagai berikut:

Tabel 5. Kepuasan Mahasiswa Menggunakan Aplikasi Google Classroom dalam Pandemi Covid 19 Pada Pembelajaran Matematika

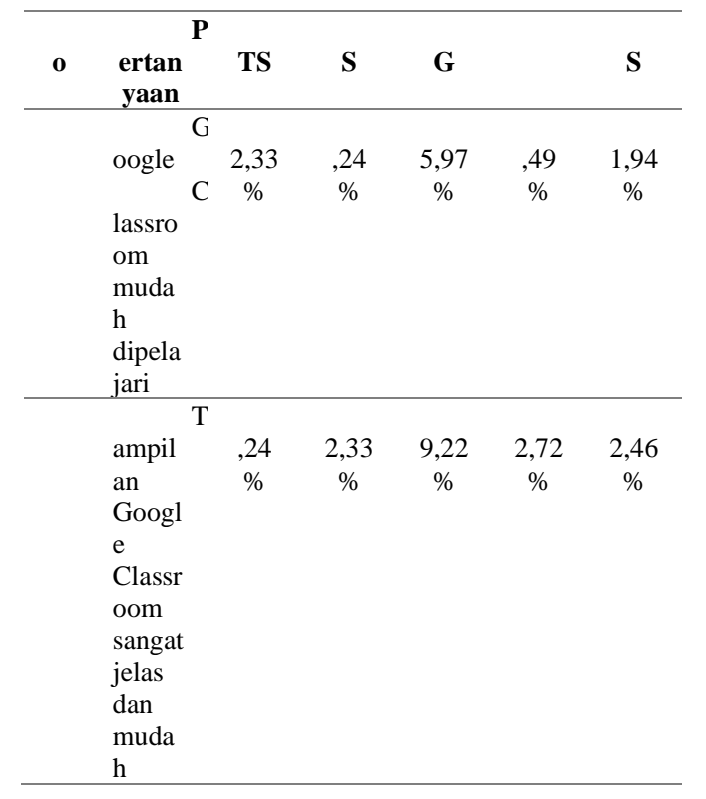


Vol I No I Mei 20ZI

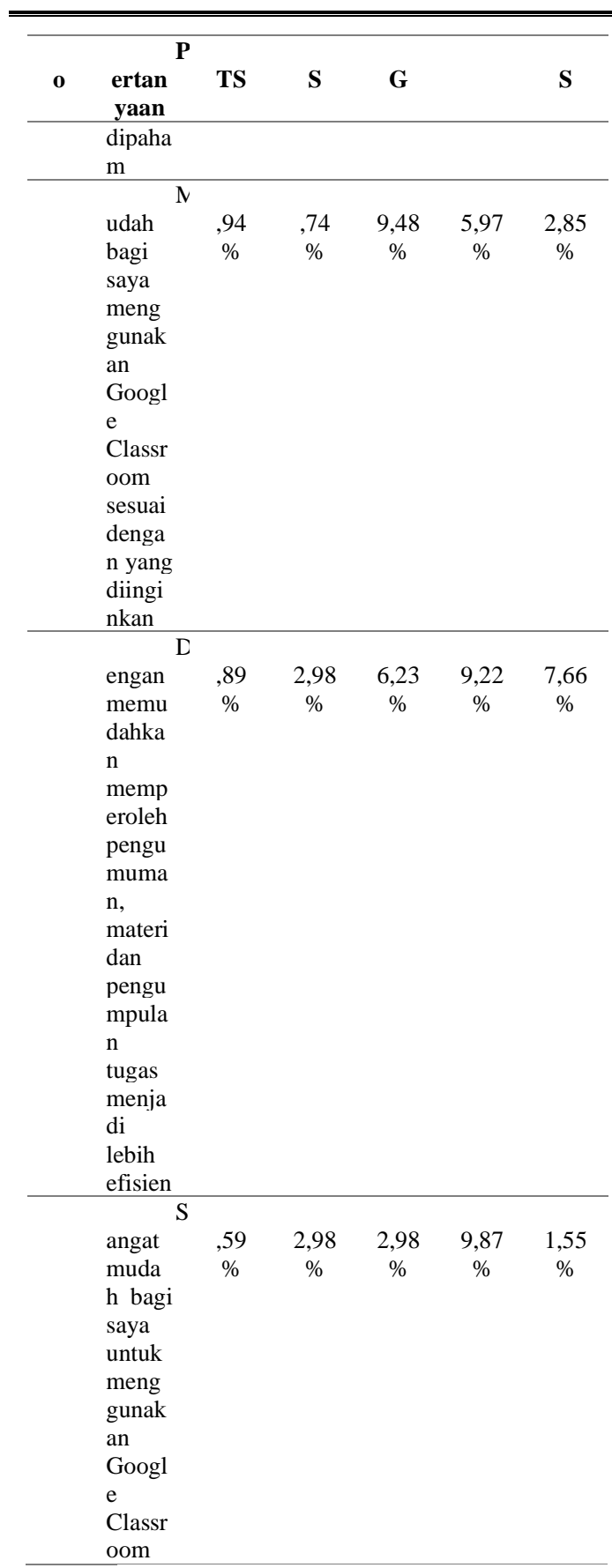

Berdasarkan hasil penyebaran angket didapatlah rata-rata hasil respon mahasiswa dalam penggunaan Aplikasi Google Classroom.

Tabel 6. Rata-rata Kepuasan Mahasiswa Menggunakan Aplikasi Google Classroom dalam Pandemi Covid 19 Pada Pembelajaran Matematika

\begin{tabular}{ccc}
\hline No & Pertanyaan & $\begin{array}{c}\text { Rata- } \\
\text { Rata }\end{array}$ \\
\hline
\end{tabular}

\begin{tabular}{clc}
\hline $\mathbf{1}$ & \multicolumn{1}{c}{$\begin{array}{c}\text { Google } \\
\text { Classroom } \\
\text { dipelajari }\end{array}$} & 3.82 \\
\hline $\mathbf{2}$ & $\begin{array}{c}\text { Tampilan Google } \\
\text { Classroom sangat jelas } \\
\text { dan mudah dipaham }\end{array}$ & 3,31 \\
\hline $\mathbf{3}$ & \multicolumn{1}{c}{ Mudah bagi saya } & 3,98 \\
& $\begin{array}{l}\text { menggunakan Google } \\
\text { Classroom sesuai } \\
\text { dengan yang diinginkan }\end{array}$ & \\
\hline $\mathbf{4}$ & $\begin{array}{l}\text { Dengan } \\
\text { memudahkan } \\
\text { memperoleh } \\
\text { pengumuman, materi } \\
\text { dan pengumpulan tugas } \\
\text { menjadi lebih efisien }\end{array}$ & \\
\hline $\mathbf{5}$ & $\begin{array}{l}\text { Sangat mudah } \\
\text { saya untuk } \\
\text { menggunakan Google } \\
\text { Classroom }\end{array}$ \\
\hline
\end{tabular}

Berdasarkan hasil penyebaran angket didapatlah rata-rata setiap itemnya, sebagai berikut:1) item 1 dengan besaran rata-rata 3,82 dapat dikatakan cukup efektif . Hal ini dapat dilihat dari angka respon yang cukup tinggi dalam mempermudah mempelajari Google Classroom; 2) item 2 dengan besaran rata-rata 3,31 dapat dikatan cukup efektif. Hal ini berkaitan dengan respon responden dalam tampilan google classroom jelas dan mudah dipahami ;3) item 3 dengan besaran rata-ratanya 3,98 dapat dikatakan efektif. Hal ini berkaitan dengan respon responden menggunakan Google Classroom sesuai dengan yang diinginkan;4) item 4 dengan rata-rata sebesar 3,83 dapat dikatakan efektif. Hal ini berkaitan dengan respon positif responden mengenai fitur gooogle classroom yang mudah serta efisien. dan 5) item 5 dengan rata-rata sebesar 3,77 dapat dikatakan efisien. Hal ini berkaitan 
denganrespon keseluruhan dari penggunaan aplikasi dirasa jelas dan mudah.

Dari hasil analisis setiap atem perskala dapat dilihat bahwa mayoritas dari responden merasa puas pada saat penggunaan Aplikasi Google classroom. Hal ini dapat dilihat dari banayaknya respon positif yang diberikan oleh responden setiap itemnya. Hal ini juga diperkuat dengan adanya wawancara dari responden $\mathrm{AB}$ yang menyatakan bahwa dalam penggunaan Aplikasi google classroom tidak ada kesulitan. Sedangkan jika dilihat pada penggunaan rata-rata respon dapat dikatan cukup efektif hal ini sejalan dengan penelitian Permata, A., \& Bhakti, Y. B. (2020) Google

Classroomkurangefektifdalampembelaja ranfisika,akantetapi sudah efektif dalam pembelajaran virtual class dan dapat digunakan sebagai aplikasi pembelajaran dimasa pandemi Covid19.

\section{PENUTUPAN}

\section{Simpulan}

Berdasarkan hasil penelitian dapat dilihat hasil simpulan dari penelitian ini adalah sebagai berikut:

1. Respon pada Aplikasi Zoom dapat dikatakan kurang efektif . Hal ini berkaitan dengan efisiensi dalam penghematan data paket mengingat pada masa pandemi, banyak orang tua yang terkena imbas dari lockdownnya kota sorong. Serta karena durasi yang lama, mengakhibatkan pemakaian batrai yang tinggi sehingga, baterai sering kehabisan. Selanjutnya signal, merupakan hal yang paling mndasar dalam pemakaian Zoom, karena kurang stabilnya signal sehingga, apa yang disampaikan tidak sampai pada mahasiswa.

2. Respon pada Aplikasi Google Classroom dapat dikatakan kurang efektif, jika mengarah pada pemanfaatan fitur-fitur yang hanya seputaran pemberian tugas dan materi non video.

\section{Saran}

Adapun saran yang dapat diberikan pada penelitian ini adalah:

1. Aplikasi Zoom hanya dapat dimanfaatkan dengan efektif jika pada daerah dengan kestabilan signal yang baik. Jika tidak, maka sebaiknya menggunakan Aplikasi yang dapat mendukung pembelajaran. Contohnya youtube. Sehingga pembelajaran dapat diputar berulang kali atau dapat diunduh. Serta, adanya upgrade dari Zoom yang mana mengurangi 
pemakaian data internet serta baterai

PC.

2. Pada Aplikasi Google Classroom diharapkan adanya fitur yang menghubungkan Google Meet pada google classroom seperti halnya pada penggunaan G suite. Serta lebih memanfaatkan video interaktif yang dapat memungkin mahasiwa mengerti sebagai salah satu strategi pembelajaran matematika di masa pandemi covid 19. 


\section{DAFTAR PUSTAKA}

Abdillah, L. A., \& Darma, U. B. (2020). Online Learning Menggunakan Zoom Teleconference.

Arikunto, S. (2010). Prosedur Penelitian Suatu Pendekatan Praktik. Edisi Revisi 2010. Jakarta: PT. Rineka Cipta. Arikunto, S. (2016). Dasar-dasar Evaluasi Pendidikan. Edisi Revisi Agustus 2016. Jakarta: PT Bumi Aksara

Arikunto, Suharsimi. (2012). Prosedur Penelitian.Jakarta: Rineka Cipta.

Gunawan, F. I., \& Sunarman, S. G. (2018, February). Pengembangan kelas virtual dengan google classroom dalam keterampilan pemecahan masalah (problem solving) topik vektor pada taruna SMK untuk mendukung pembelajaran. In Prosiding Seminar Nasional Pendidikan Matematika Etnomatnesia.

Hartanto, W. (2016). Penggunaan E-Learning Sebagai Media Pembelajaran. Jurnal Pendidikan Ekonomi: Jurnal Ilmiah Ilmu Pendidikan, Ilmu Ekonomi dan Ilmu Sosial, 10(1).

Ismawati, D., \& Prasetyo, I. (2020). Efektivitas Pembelajaran Menggunakan Video Zoom Cloud Meeting pada Anak Usia Dini Era Pandemi Covid-19. Jurnal Obsesi: Jurnal Pendidikan Anak Usia Dini, 5(1), 665-675.

Kusuma, J. W., \& Hamidah, H. (2020). Perbandingan Hasil Belajar Matematika Dengan Penggunaan Platform Whatsapp Group Dan Webinar Zoom Dalam Pembelajaran Jarak Jauh Pada Masa Pandemik Covid 19. JIPMat, 5(1).

Monica, J., \& Fitriawati, D. (2020). Efektivitas Penggunaan Aplikasi Zoom Sebagai Media Pembelajaran Online Pada Mahasiswa Saat Pandemi Covid-19. Jurnal Communio: Jurnal Jurusan Ilmu Komunikasi, 9(2), 1630-1640.

Nurani, N. I., Uswatun, D. A., \& Maula, L. H. (2020). Analisis Proses Pembelajaran Matematika Berbasis Daring Menggunakan Aplikasi Google Classroom Pada Masa Pandemi Covid19. Jurnal PGSD, 6(1), 50-56.

Permata, A., \& Bhakti, Y. B. (2020). Keefektifan Virtual Class dengan Google Classroom dalam Pembelajaran Fisika Dimasa Pandemi Covid-19. JIPFRI (Jurnal Inovasi Pendidikan Fisika Dan Riset Ilmiah), 4(1), 27-33.

Rohiman, R., \& Anggoro, B. S. (2019). Penggunaan Prezi untuk Media Pembelajaran Matematika Materi Fungsi. Desimal: Jurnal Matematika, 2(1), 23-32.

Sabran, S., \& Sabara, E. (2019, February). Keefektifan Google Classroom sebagai media pembelajaran. In Seminar Nasional LP2M UNM.Sugiyono. (2016). Metode Penelitian Pendidikan pendekatan kuantitatif, kualitatif dan R\&D. Alfabeta: Bandung

Slameto. (2010). Belajar dan faktor-faktor yang mempengaruhinya. Jakarta: Rineka Cipta

Trianto. 2015. Model Pembelajaran Terpadu. Jakarta: PT Bumi Aksara.

Utami, R. (2019, February). Analisis Respon Mahataruna terhadap Penggunaan Google Classroom pada Mata Kuliah Psikologi Pembelajaran Matematika. In Prisma, Prosiding Seminar Nasional Matematika (Vol. 2, pp. 498-502). 